\title{
Distribution of some Calanoida (Crustacea: Copepoda) from the Yucatán Peninsula, Belize and Guatemala
}

\author{
Gerd-Oltmann Brandorff \\ Georg-Gröning-Str. 29 A, D-28209 Bremen, Germany; gobrandorf@aol.com
}

\author{
Received 07-III-2011. C Corrected 22-VII-2011. Accepted 29-VIII-2011.
}

\begin{abstract}
Southern Mexico and Central America have many water bodies of different morphology and water chemistry with an interesting zooplankton fauna, originating from North or South America. A set of 63 samples, taken in 2005 and 2008, from water bodies of the Yucatan Peninsula karst, Belize and Guatemala, were studied for the content of calanoid copepods. Old and recent literature was used to determine animals to species level. Drawings were prepared with a microscope and a camera lucida. A total of 32 samples with totally six species contained calanoid copepods: one estuarine pseudodiaptomid and five freshwater diaptomids. Pseudodiaptomus marshi was found at different salinities. It is confirmed that the commonest diaptomids in the Yucatan Peninsula are Arctodiaptomus dorsalis and Mastigodiaptomus nesus. The former was also recorded from Lake Amatitlan. Mastigodiaptomus nesus is as widespread as A. dorsalis but it is absent from the Lake Peten area in Guatemala. Mastigodiaptomus reidae was found in two shallow habitats, these specimens differ from those from the type locality by having a set of peculiar large spine-like processes on the last thoracic and the urosome segments of the females. Leptodiaptomus siciloides was found only in Lake Ayarza with high salinity. Prionodiaptomus colombiensis occurred in the highlands of Guatemala in Lago de Güija and in the Peten area in Laguna Sacpuy. We contributed with our occurrence records to a better knowledge of the geographic distribution of some calanoid copepods. Morphological findings in some species are of value for taxonomic differentiation between species. Rev. Biol. Trop. 60 (1): 187-202. Epub 2012 March 01.
\end{abstract}

Key words: Central America, zooplankton, calanoid copepods, Pseudodiaptomidae, Diaptomidae, geographic distribution.

Mexico, Central America and the Caribbean, as a bridge between North and South America, host many species from two distinct biogeographical regions, the Nearctic and Neotropical. It is also called Neotropical-Caribbean (NCAR) (Dussart \& Defaye 2001). Zooplankton represents an important community to transfer matter and energy between producers and consumers in food webs, thus shaping the pelagic ecosystem. Copepods make up a major portion of the biomass and productivity of freshwater ecosystems (Williamson \& Reid 2001). Nine genera with 26 species of diaptomid copepods (Crustacea) are registered (SuárezMorales et al. 2005), five genera from the Nearctic, one from South America, two NCAR genera, and one (Diaptomus s.l.) with unclear taxonomical classification. From the tropical Yucatan Peninsula and Guatemala three genera with seven species and one pseudodiaptomid copepod are known.

Decades ago Dussart et al. (1984) considered the Central American region as "well studied" for the freshwater copepods. Although, new species have been described, especially from Mexico (Suárez-Morales \& ElíasGutiérrez 2000), Elías-Gutiérrez et al. (2008a) showed that there are still many overlooked/ cryptic species of Diaptomidae in the region to be morphologically described. But, there are still many water bodies to be sampled, for instance, Yucatan cenotes and lakes in adjacent 
areas (Alcocer \& Bernal-Brooks 2010). So it was a good opportunity to look at the samples from the Yucatan Peninsula, Belize and Guatemala that were presented to me and to see what calanoid species they contain. In this contribution the results of the extensive sampling of calanoid copepods of inland waters are presented, and comparative morphological and distributional comments about the species are provided herein.

\section{MATERIALS AND METHODS}

In 2005 and 2008 Burkhard Scharf, Liseth Pérez and co-workers from the Institute of
Environmental Geology of the University of Braunschweig, Germany sampled freshwater habitats in the Yucatan lowlands of Mexico, Belize and Guatemala (Pérez et al. 2010). The aim of their project was to use ostracods from the Yucatán Peninsula as indicators of past environmental and climate change. Sampled sites included: lakes, sinkholes, brackish water lagoons, rivers in the lowlands, and lakes in the Guatemalan highlands (Fig. 1, Tables 1,2).

Water samples to determine physico-chemical variables as temperature, $\mathrm{pH}$, conductivity and oxygen were taken with a Ruttner-sampler and measured with a WTW multisensor equipment. Qualitative samples of plankton in the

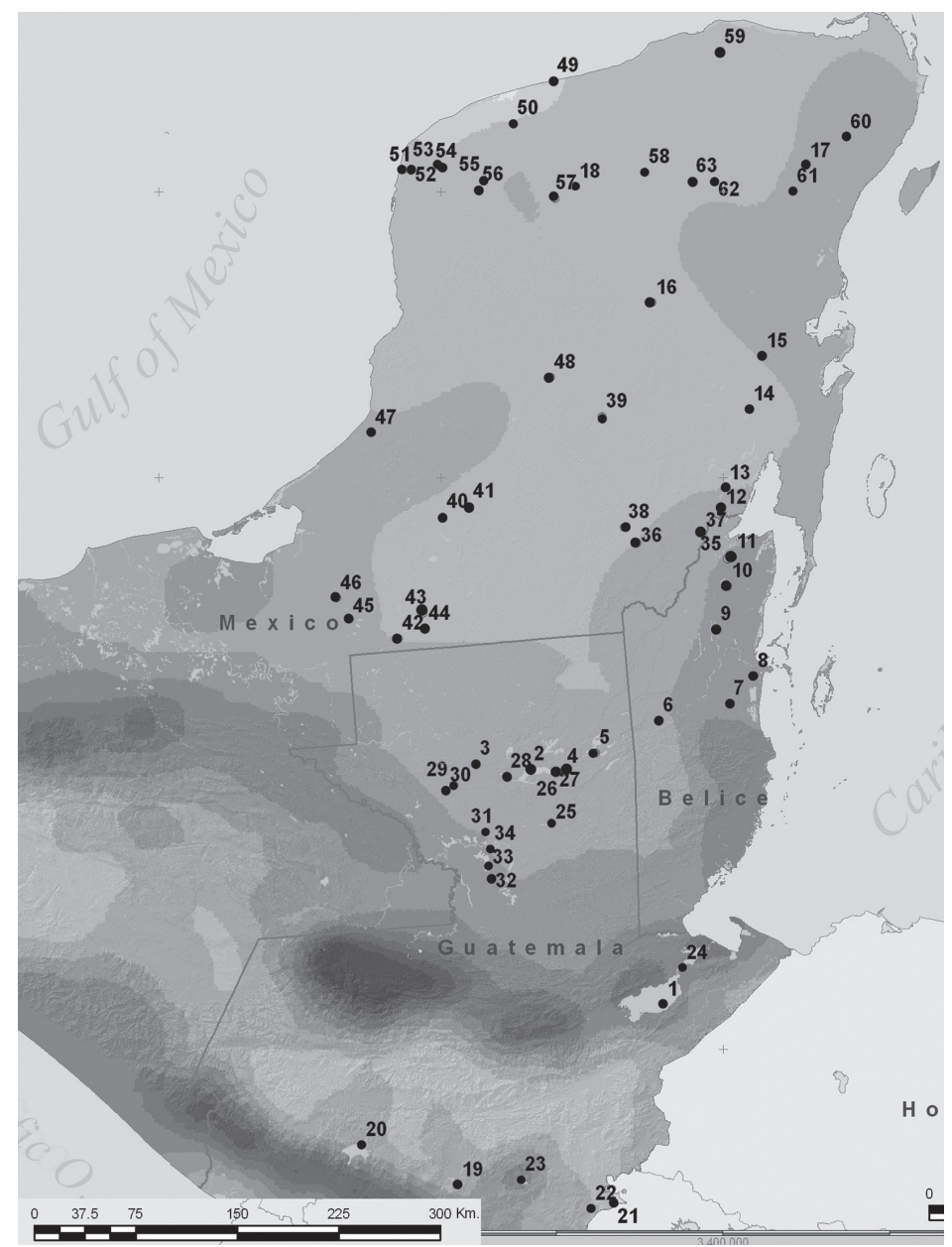

Fig. 1. Sampled water bodies in 2005 and 2008, their numbers and geographical position. 


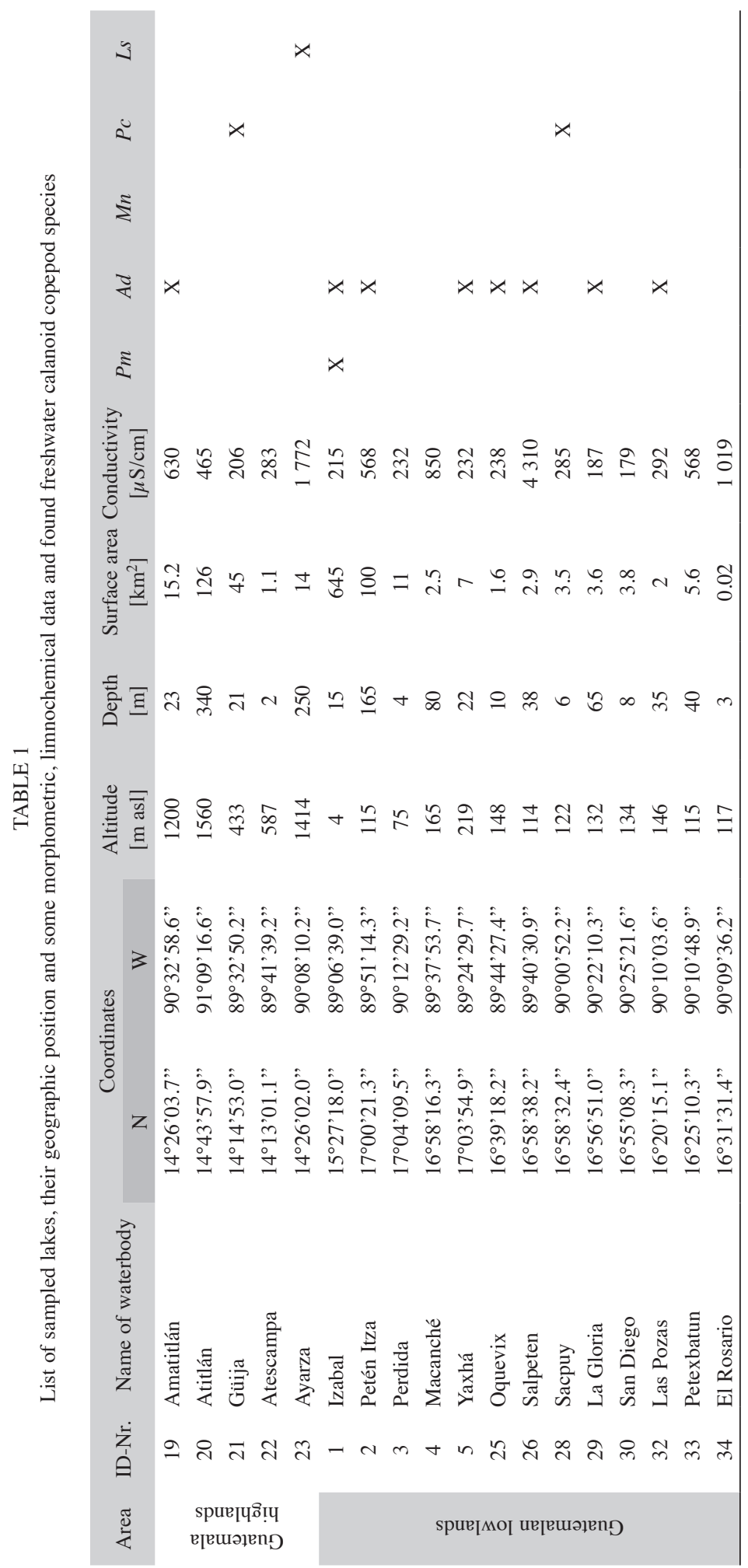




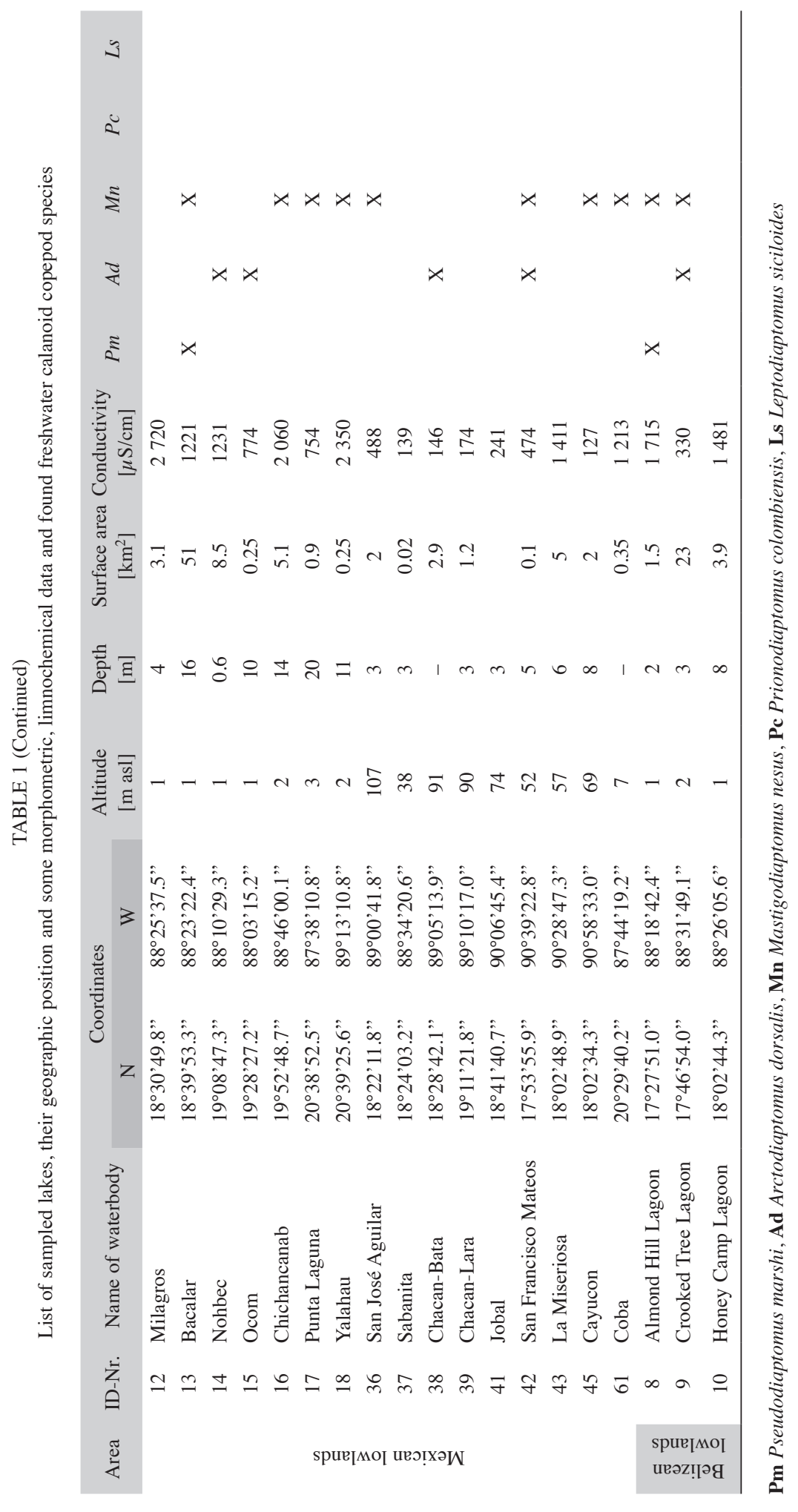




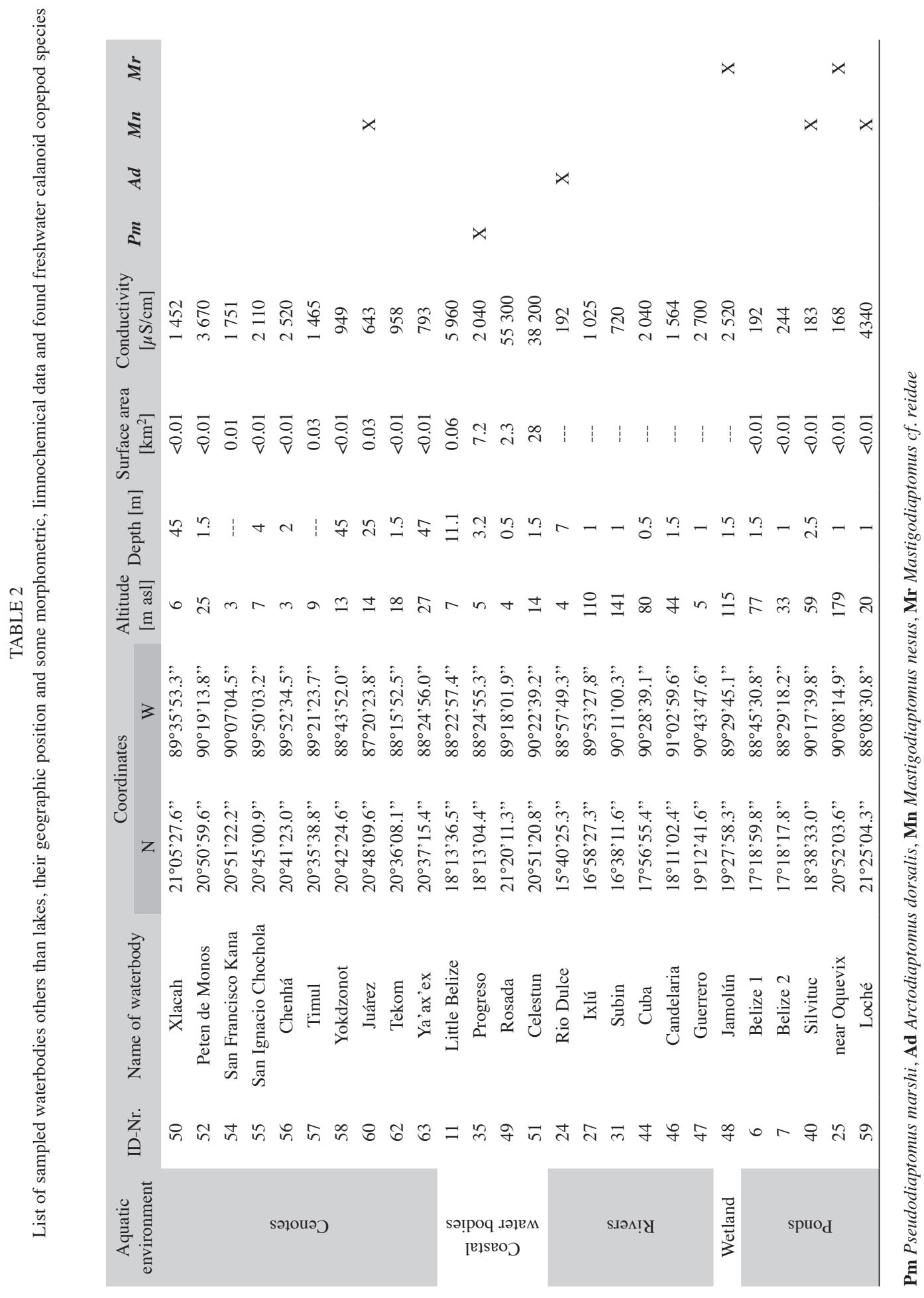


open water and the littoral were taken using standard plankton net with $100 \mu \mathrm{m}$ mesh size, fixed and preserved in $4 \%$ formalin. In the laboratory, adult calanoid copepods were sorted under an Olympus dissecting microscope, and identified to the species level with an Olympus $\mathrm{CH} 2$ microscope. The following literature was used: Light (1939), Bowman (1986), Gutiérrez-Aguirre \& Suárez-Morales (2000), Suárez-Morales \& Elías-Gutiérrez (2000, 2001), and Elías-Gutiérrez et al. (2008b). Drawings were prepared with the Olympus $\mathrm{CH}$ 2 microscope, and a camera lucida attached to the microscope at $40 \mathrm{x}$ magnification. The salinity classification of the lakes follows Cowardin et al. (1979).

\section{RESULTS}

Tables 1 and 2, list species of calanoid copepods from the lakes and other water bodies, like cenotes, ponds, coastal water bodies and rivers, in Yucatan Peninsula, Guatemala and Belize, arranged according to Pérez et al (2010). Only 32 of the 63 sampled water bodies contained calanoid copepods. Fig. 1 shows the sampled water bodies, their numbers and geographical position and figure 2 shows the geographical distribution of the species found in the sampled area. Pseudodiaptomus marshi Wright, 1936 occurred in four water bodies with fresh to oligosaline waters at nearly sea level (Fig. 2c). Our specimens from Lago Izabal, Progreso Lagoon and Almond Hill Lagoon
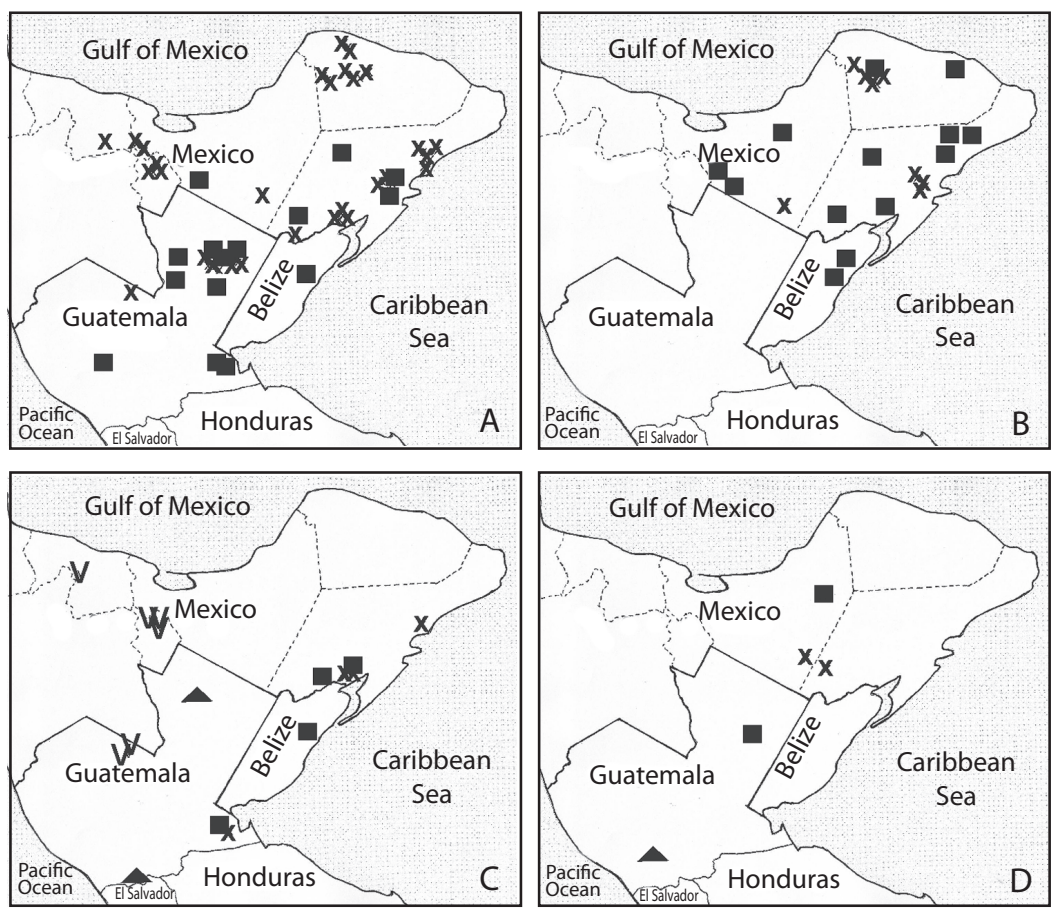

Fig. 2. Distributional patterns of the calanoid copepods found in our samples. a) Arctodiaptomus dorsalis, records from other authors (X) (Brinson \& Nordlie 1975, Deevey 1980, Suárez 1991, Flores-Nava 1994, Gutiérrez-Aguirre \& Suárez-Morales 2001, Elías-Gutiérrez et al. 2008a, b). b) Mastigodiaptomus nesus, records from other authors (X) (Elías-Gutiérrez et al. 2008a). c) Pseudodiaptomus marshi (rectangles) and Prionodiaptomus colombiensis (triangles), records from other authors (X for P. marshi and V for P. colombiensis) (Brinson \& Nordlie 1975, Gutiérrez-Aguirre \& Suárez-Morales 2001, ElíasGutiérrez et al. 2008a, b). d) Leptodiaptomus siciloides (triangles) and Mastigodiaptomus cf. reidae (rectangles), data from other authors (X for M. reidae) (Suárez-Morales \& Elías-Gutiérrez 2000, Elías-Gutiérrez 2008b). 
possess an anterolateral knob with many spines and hairs on the right side of female's genital somite (Fig. 3).

Arctodiaptomus dorsalis (Marsh, 1907) was found in 14 water bodies that lie below an altitude of 200m.a.s.1., and in Lago Amatitlán (Guatemala) at 1 195m.a.s.l. (Fig. 2a). One of these 14 water bodies (Lago Salpeten, Guatemala) is oligohaline.

Mastigodiaptomus nesus (Bowman, 1986) was in 13 water bodies in the Yucatán Peninsula at altitudes below 100m.a.s.l. (Fig. 2b). Six lakes of this cluster are oligohaline. A.dorsalis and $M$. nesus co-occurred in three lakes.

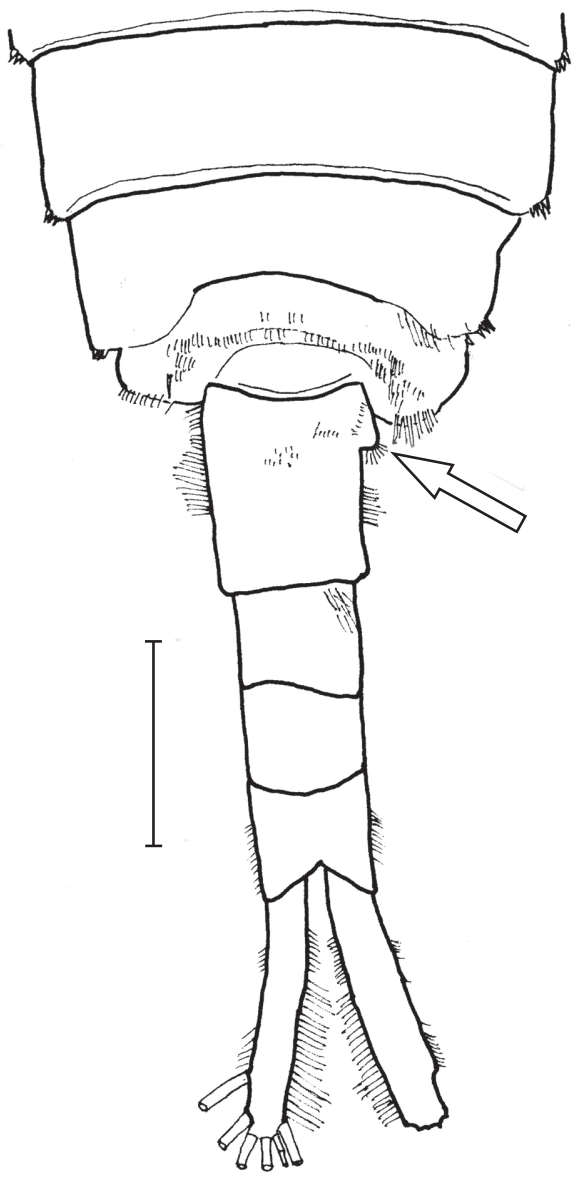

Fig. 3. Pseudodiaptomus marshi, female last pedigerous somites and urosome, scale bar $0.1 \mathrm{~mm}$, arrow indicates anterolateral knob.
In a pool and a wetland area (Fig. 2d) animals were found that resemble very much Mastigodiaptomus reidae Morales \& ElíasGutiérrez, 2000. The two water bodies contain fresh water and lie at an altitude of about 100 m.a.s.l. Morphologically there are some differences between our specimens and $M$. reidae, especially in the female (Fig. 4 a,b). On the not well developed border between pediger four and five on the posterior surface on each side of the dorsal process we found two long, flexible spine-like processes, their length is about 25 and $30 \mu \mathrm{m}$. The dorsal process or hump we found only in some specimens. Spine-like processes on left and right thoracic wing are on the same position as described in $M$. reidae, but are larger (about $25 \mu \mathrm{m}$ ) in our specimens. About this same length was found for the two spines on the anterior third of the long urosome. The caudal rami have an inner and outer setose margin. Other morphological features are as

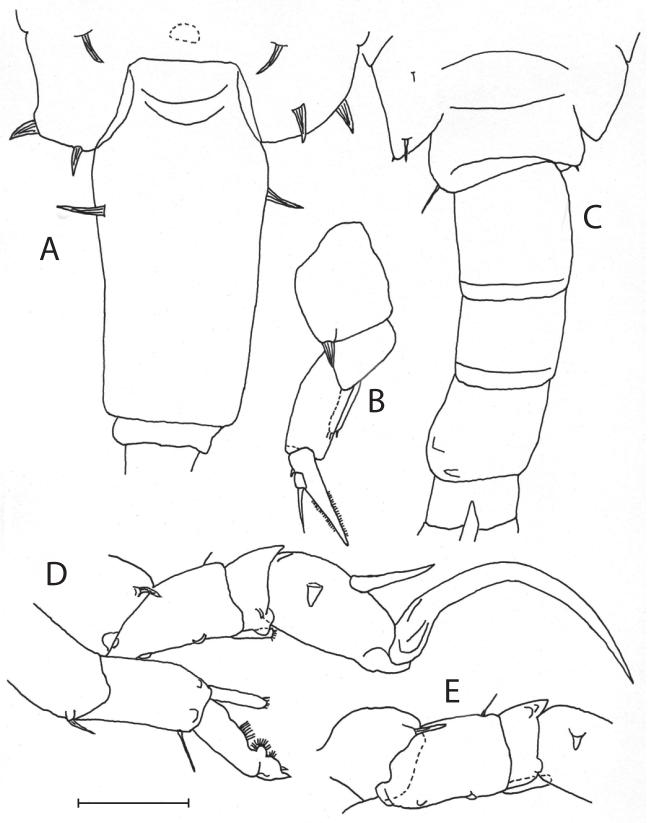

Fig. 4. Mastigodiaptomus $c f$. reidae: a) last pedigerous somite and genital somite of female, b) left $\mathrm{P}_{5}$ of female, c) last pedigerous somite and urosome of male, d) $\mathrm{P}_{5}$ of male, e) part of right $P_{5}$ of male (another specimen) showing the ornamentation of exopodite 1 , scale bar $0.1 \mathrm{~mm}$. 
in $M$. reidae. The male (Fig. 4 c-e) does not differ from the description of $M$. reidae. Most morphological differences between $M$. reidae and our specimens are small and probably lie within the species range. Only the spine-like processes on the female's pediger $4 / 5$ were remarkable and never seen in other specimens. Normally on this position one can find short fine hairs in many species. The morphologic variability in the $M$. cf. reidae females was conservative into and between surveyed populations (Oquevix pond and Jamolún wetland).

Prionodiaptomus colombiensis (Thiebaud, 1912) was found in two freshwater bodies in Guatemala at altitudes of 433 m.a.s.l. and 206m.a.s.1. (Fig. 2c), respectively. In our specimens from Lake Güija we found, on the females genital segment, a fold on the ventroposterior region that is crescent shaped (Fig. 5, double-arrow).

Leptodiaptomus siciloides (Lilljeborg, 1889 in De Guerne \& Richard) was found only in one highland lake (Fig. 2d) at an altitude of 1414 m.a.s.l. with oligosaline water.

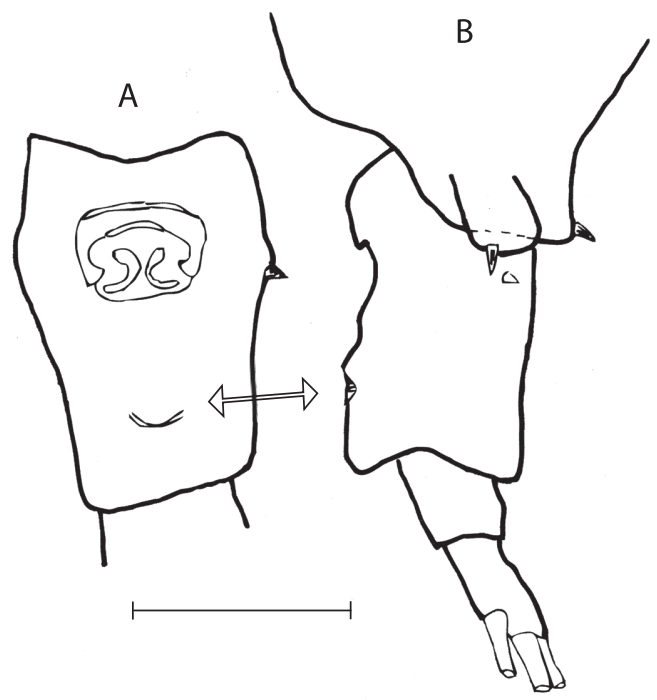

Fig. 5. Ventral (a) and lateral (b) view of genital segment of female Prionodiaptomus colombiensis with crescent shaped fold (arrow), scale bar $0.1 \mathrm{~mm}$.

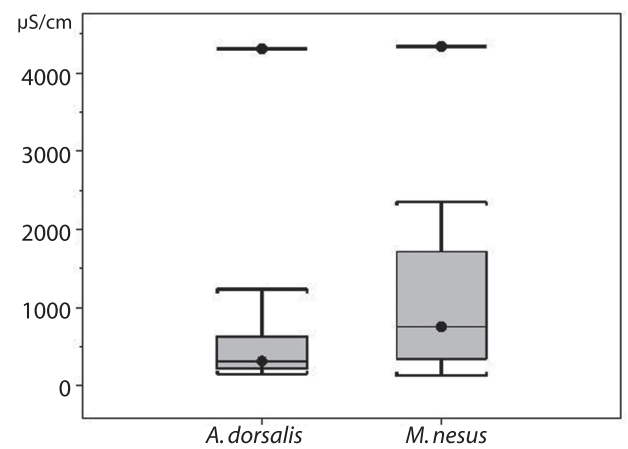

Fig. 6. Box plots of Arctodiaptomus dorsalis and Mastigodiaptomus nesus and the conductivity of the sampled water bodies.

Conductivity ranges of the water bodies where A.dorsalis and M. nesus were found, are shown in figure 6.

\section{DISCUSSION}

An interpretation of some limnological and morphological characteristics, physical and chemical properties of the sampled water bodies waters has already been published (Pérez et al. 2010). From the 63 samples, taken in 2005 and 2008, only 32 contained calanoid copepods. The reasons why nearly $50 \%$ of the samples had no Calanoida can be numerous: wrong season, inadequate water chemistry, not enough food, predation, among others. Nine out of the 32 water bodies with Calanoida were sampled before by other authors. From the sampled region, one pseudodiaptomid and nine diaptomid species were known. We found one pseudodiaptomid and five diaptomid species, none of them was new, but we could add some new occurrences.

The taxonomy of the Mexican species of Diaptomidae have made great progress in the last decades (Elías-Gutiérrez et al. 2008b), but still some species complexes with overlooked species, as in A. dorsalis and Mastigodiaptomus albuquerquensis, have to be cleared (Elías-Gutiérrez et al. 2008a). Therefore it 
is worth to note morphological differences in some species.

Pseudodiaptomus marshi (Wright, 1936): is a widespread species in estuaries on the Atlantic coast of Central and South America, extending South to Vitória, Espirito Santo, Brazil $\left(20^{\circ} 16^{\prime} \mathrm{S}\right)$ (Pereira \& Loureiro Fernandes 2000, Santos Silva 2008). Brinson \& Nordlie (1975) reported it as its Pacific sibling P. culebrensis from Lago Izabal.

The estuarine species $P$. marshi can live in a wide range of salinity, from fresh water (Lago Izabal) to salinities up to 42ppt (Medeiros et al. 2006) in Northeastern Brazil. In the Yucatan Peninsula, the distribution was found mostly well inside the coastline (e.g. Laguna Bacalar), that might have resulted from stranding and subsequent adaptation to freshwater during a marine regression in the Bacalar formation (Suárez-Morales 2003).

Our results of the anterolateral knob on the females genital somite in P. marshi, is in accordance with the material from Costa Rica and Belize (Walter 1989), for which the genital somite of specimens from Central America is asymmetrical, whereas from West Indies and South America it is symmetrical. Also ElíasGutiérrez et al. (2008b) showed an asymmetrical genital somite from Mexican specimens, among others from Laguna de Bacalar.

Arctodiaptomus dorsalis (Marsh, 1907): Its core range lies in tropical and subtropical lowlands bordering the Gulf of Mexico and Caribbean Sea, from the Southern United States through Central America and Northern South America, plus the Greater Antilles (Reid 2007). In North America it extends its range by human agency.

In the studied area, it has a somewhat disjunct distribution: in the Eastern coastal zone of Quintana Roo, in the North-western part of the State of Yucatán round the city of Mérida, the Petén area in Guatemala, and the South-East of Tabasco. A similar picture for the distribution in the Yucatan Peninsula is drawn by Suárez-Morales (2003). He also discusses the dispersal through geological times.
According to Schmitter-Soto et al. (2002) A. dorsalis is the dominant copepod in the central epicontinental portion of the Yucatan Peninsula and is substituted in other portion by Mastigodiaptomus ssp. Neighboring, there are some isolated occurrences in Campeche and a cluster in Tamaulipas. In Guatemala A. dorsalis is widely distributed in the Petén district (Deevey et al. 1980, this study) and in Lago Izabal and Río Dulce (Brinson \& Nordlie 1975, this study). Isolated occurrences were found in Lago Lachuá near the Mexican border (Elías-Gutiérrez et al. 2008a). The presence in Lake Amatitlán (this study) was a great surprise. But only two males and two females were found. Nearly 100 years before (1910) Mastigodiaptomus albuquerquensis (Herrick, 1895) and M. amatitlanensis (Wilson, 1941) were reported (Juday 1915, Wilson 1941). Only more intensive sampling can show, if there is a real change in species and if the massive eutrophication of the lake favored A. dorsalis and excluded the Mastigodiaptomus species.

Mastigodiaptomus nesus (Bowman, 1986): It is distributed in the Yucatán Peninsula (Suárez-Morales 2003) and the Northern Caribbean Islands (Bowman 1986, Reid \& Hribar 2006). In the Yucatán Peninsula it shows a scattered distribution in the lowlands of México and Belize. We found it in coastal lagoons, lakes, ponds and cenotes, but it was also found in wells, cave pool, potholes and cenote-like pits (Bowman 1986), the extremes are Blue Holes where it was caught in depths up to $50 \mathrm{~m}$ (Fosshagen \& Iliffe 2003, 2004). In the deep Minicenote it is present throughout the year and seems to make horizontal migrations to the walls of the cenote to escape predation (Cervantes-Martínez et al. 2005). It was found at very different salinities: from fresh water (Laguna Cayucón), different higher salinities in the Yucatán Peninsula to marine salinities (Fosshagen \& Iliffe 2004). So M. nesus is called a halotolerant form. The biogeography of this species during geological development of Central America is given by Suárez-Morales \& Reid (2003). 
Mastigodiaptomus cf. reidae SuárezMorales \& Elías-Gutiérrez, 2000: M. cf reidae as is M. reidae (Suárez-Morales \& ElíasGutiérrez 2000) are relatively large diaptomids. All were from the same area and from shallow ponds. Their body size can be explained with the lack of fish as predators, which cannot survive in these water bodies that are in part ephemeral. A similar phenomenon was observed in the Pantanal, Brazil with Argyrodiaptomus nhumirim (Reid 1997, Brandorff et al. 2011).

The dorsal process or hump occurs in many species of different genera, mostly is very variable and therefore has no taxonomic value (Wright 1927, Suárez-Morales \&
M. reidae were found (Elías-Gutiérrez et al. 2008a). Our specimens came from the same type of habitat and also from the lowlands of Yucatán; whether it is one of the Kohunlich species or a different one must be proven.

Reid et al. (2002) pointed out that the habitats of M. reidae and M. maya will be exposed to great human pressure because of increasing tourism development in the archaeological sites. These species from this area and the specimens from the pond near Lake Oquevix should be considered vulnerable.

Prionodiaptomus colombiensis (Thiebaud, 1912): This species was found only in two samples from Laguna Sacpuy in Guatemala

TABLE 3

Female/male body size ratio of different Mastigodiaptomus species from published literature

\begin{tabular}{|c|c|c|c|c|}
\hline \multirow{2}{*}{$\begin{array}{c}\text { Mastigodiaptomus } \\
\text { species }\end{array}$} & \multicolumn{2}{|c|}{$\mathrm{mm}$} & \multirow{2}{*}{ Ratio } & \multirow{2}{*}{ Author } \\
\hline & Female & Male & & \\
\hline M. albuquerquensis & 1.77 & 1.58 & 1.12 & Marsh 1907 \\
\hline M. purpureus & 2.56 & 2.24 & 1.14 & Marsh 1907 \\
\hline M.nesus & 1.48 & 1.34 & 1.10 & Bowman 1986 \\
\hline M. montezumae & 1.59 & 1.43 & 1.11 & Santos Silva et al. 1996 \\
\hline M. amatitlanensis & 1.45 & 1.33 & 1.09 & Wilson 1941 \\
\hline M. maya & 2.38 & 2.18 & 1.09 & Suárez-Morales \& Elías-Gutiérrez 2000 \\
\hline M. reidae & 1.54 & 1.56 & 0.99 & Suárez-Morales \& Elías-Gutiérrez 2000 \\
\hline
\end{tabular}

Elías-Gutiérrez 2000). Spine-like processes on left and right thoracic wing are on the same position as described by Suárez-Morales \& Elías-Gutiérrez (2000), but are larger (about $25 \mu \mathrm{m})$ in our specimens. About the same length are the two spines on the anterior third of the long urosome. The caudal rami have an inner and outer setose margin. Striking is the low female/male ratio of 0.99 in $M$. reidae (Table 3), since normally the ratio is greater than one and lies between 1.01 and 1.24 (Cicchino et al. 2001).

$M$. reidae has been found in a small pond in Chicaná, Campeche (Suárez-Morales \& Elías-Gutiérrez 2000); and also in a small pond at Kohunlich, Quintana Roo, where two other morphologically similar but distinct species of and Lago de Güija. On previous reports about the zooplankton of this lake, only immature Diaptomidae were found (Marsh 1931). In June 1980 Mastigodiaptomus albuquerquensis (Herrick, 1895) was found in Lago de Güija (Serruya \& Pollingher 1983), while in our sample from the same lake, $P$. colombiensis was the only planktonic diaptomid.

One of the tables summarizes the published records on which $P$. colombiensis have been found and therefore its actual known distribution (Table 4). The Northern most point is in Mexico and the Southernmost in Colombia. According to Suárez-Morales et al. (2005) it is a South American genus and the only one "that has radiated through Central America and reach Mexico". The water bodies altitudes varied 


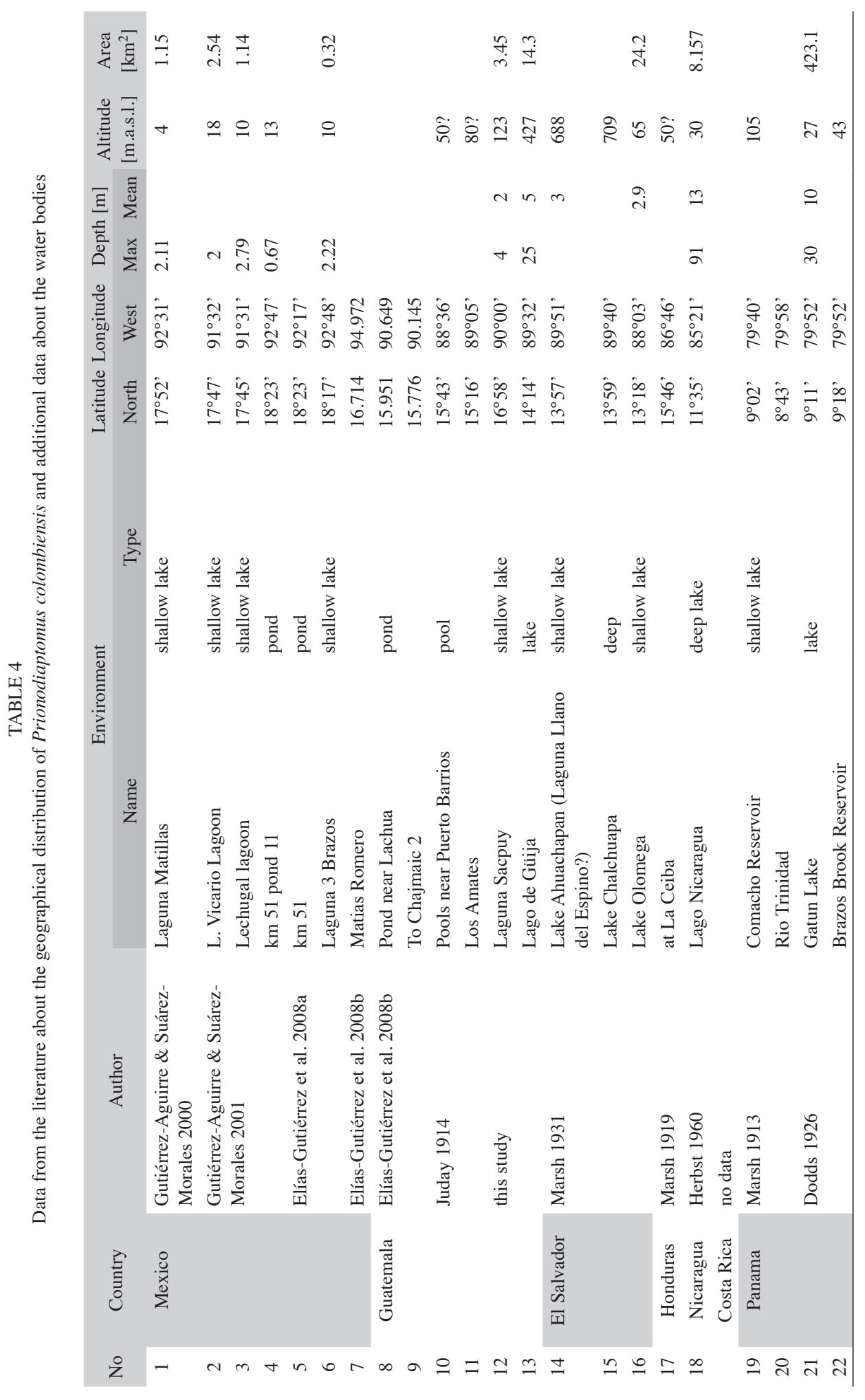




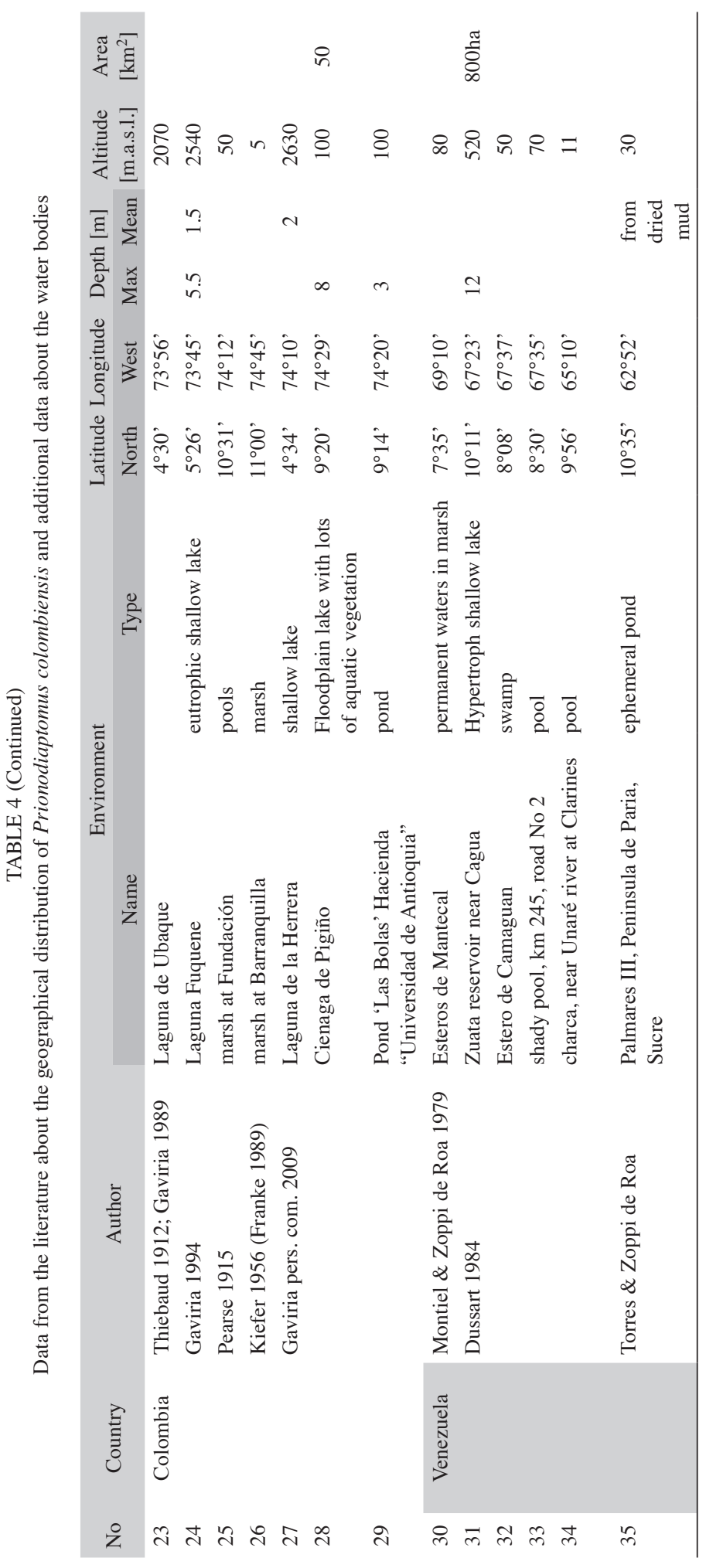


from nearly sea level $(4 \mathrm{~m})$ to $2540 \mathrm{~m}$ in the Colombian Andes, but more than $70 \%$ lie at an altitude between 0 and $100 \mathrm{~m}$.

$P$. colombiensis was found in water bodies of very different sizes: from small ponds and marshes to lakes of over $8000 \mathrm{~km}^{2}$. Most samples were from small, shallow lakes, ponds and marshes. Water bodies with a greater surface area mostly were shallow and with much aquatic vegetation, like Lake Güija (Guatemala/El Salvador). In the large Lake Nicaragua $P$. colombiensis was taken from the shore (Herbst 1960, Hartmann 1959). Nearly all records indicate that $P$. colombiensis is a species living in small pools or ponds, in vegetated lakes or on the shore of lakes. This is confirmed by Dodds (1926) from Gatun Lake (Panama), where it was found in shores and ponds, but always in small numbers, except in a very dirty and plant grown pond between Gamboa and Summit, where it was the most abundant species. In Gatun Lake itself Diaptomus s.l. gatunensis Marsh, 1913 is the abundant diaptomid (Zaret \& Suffern 1976). Also Marsh (1931) stated that for $P$. colombiensis "its preferred habitat is in shallow water or pools". In summary, P. colombiensis dwells in shallow lakes, in the littoral and/or within the macrophytes.

In describing the species of Prionodiaptomus incarum from Peru, Cicchino et al. (2004) showed on the female genital segment "ventroposterior region with very conspicuous semicircular fold with adjacent wrinkled area medially, reaching posterior margin of genital double-somite". They pointed out that also specimens from Venezuela of $P$. colombiensis have this morphological peculiarity. In our specimens it is crescent shaped. Further studies have to show if it is characteristic for the genus Prionodiaptomus and its function. A good overall morphological description and variation is given by Gutiérrez-Aguirre \& SuárezMorales (2000).

Leptodiaptomus siciloides (Lilljeborg, 1889 in De Guerne \& Richard): This species was only found in Laguna de Ayarza, a figure8-shaped doublecaldera lake in the Guatemalan highlands. The lake lies at an altitude of $1414 \mathrm{~m}$.a.s.l., maximum depth is $250 \mathrm{~m}$ and conductivity between 1772 and $1844 \mu \mathrm{S} / \mathrm{cm}$. A comparable habitat is Lago Ilopango in El Salvador, a lake of volcanic origin at an altitude of 490 m.a.s.1., with a maximum depth of $215 \mathrm{~m}$ and conductivity between 1.45 and $2.09 \mathrm{mS}$ (Gophen \& Walline 2005). There L. siciloides was found by Juday (1915), present at all depths, but most abundant between 10 and $25 \mathrm{~m}$, together with numerous protozoan Tintinnidae. Also present was the euryhaline rotifer Hexarthra fennica; it was also reported from Lago Chamico in El Salvador (Marsh 1931), a deep volcanic lake. These lakes in Guatemala and El Salvador seem to be the southernmost points of the L. siciloides geographical distribution. The geographical range covers the USA and Southern Canada (Suárez-Morales et al. 2005). In Wisconsin (Torke 2001) L. siciloides is fairly common in permanent ponds, lakes and reservoirs. It prefers more eutrophic habitats and this selection let it expand to new habitats due to cultural eutrophication of many lakes and ponds in this state.

In Mexico it is widely distributed in the states of Aguascalientes, Puebla, Coahuila and Sonora (Suárez-Morales et al. 2005, ElíasGutiérrez et al. 2008b). In Aguascalientes state L. siciloides was found at altitudes between 1 850 and 2010 m.a.s.1., in permanent and nonpermanent water bodies, with different surface areas and maximum depth (Dodson \& SilvaBriano 1996). Other limnological data were not reported but probably cover a wide range.

In two of the sampled water bodies, $A$. dorsalis and M. nesus co-occurred (lake San Francisco de Mateos, Mexico and Crooked Tree Sanctuary Lagoon, Belize); the same co-occurrence was reported from Minicenote (Elías-Gutiérrez et al. 2008b). Species of the same genus or family can coexist if their temporal and spatial occurrence, their body size, and/or their ecological requirements are different. In this case A. dorsalis is about $16 \%$ smaller than $M$. nesus. Looking at the conductivity of the water bodies where they were found, we can say that $M$. nesus has a higher 
median and a greater range of variation, but the outlier in A.dorsalis was as high $(4310 \mu \mathrm{S} /$ cm Lake Salpeten, Guatemala) as in M. nesus (4 $340 \mu \mathrm{S} / \mathrm{cm}$ in Loché pond, Mexico). Apart from the differences, an overlap in conductivity data is given (Fig. 6).

A. dorsalis also coexists with Pseudodiaptomus marshi in Lago Izabal (this study, Brinson \& Nordlie 1975), Laguna de Bacalar, Cenote Mayan Blue and Puente Milagros (Elías-Gutiérrez et al. 2008b), with Prionodiaptomus colombiensis in L. Vicario Lagoon and Matillas Lagoon (Gutiérrez-Aguirre \& Suárez-Morales 2001), and with Mastigodiaptomus texensis in Mytza Quarry (Flores-Nava 1994). M. nesus was found together with $P$. marshi in Laguna de Bacalar and Almond Hill Lagoon, Belize (this study).

\section{ACKNOWLEDGMENTS}

I am greatly indebted to Burkhard Scharf, Bremen and Liseth Pérez, Braunschweig, who made the samples available for me to study the calanoids. I like to thank Janet Reid, USA for giving me the hint that our specimens from Oquevix are very close to $M$. reidae. Santiago Gaviria from Vienna, Austria provided me with a lot of information about the ecology of Prionodiaptomus colombiensis what I greatly appreciate. Manuel Elías-Gutiérrez from Mexico made it possible to study his book recently published about the Cladocera and Copepoda from Mexico.

\section{RESUMEN}

El sur de México y América Central tienen varios cuerpos de agua con diferente morfología, composición química y una interesante fauna de zooplancton procedente de América del Norte o del Sur. Un grupo de 63 muestras, fueron tomadas en 2005 y 2008 para conocer la cantidad de copépodos calanoides en los cuerpos de agua del karst Península de Yucatán, Belice y Guatemala. Se utilizó literatura antigua y reciente para la identificación de los especímenes a nivel de especie y se preparon dibujos con un microscopio y una cámara lúcida. En un total de 32 muestras se obtuvieron seis especies de copépodos calanoides: un pseudodiaptomidos estuarino y cinco diaptomidos de agua dulce. Pseudodiaptomus marshi fue encontrado a diferentes salinidades. Además, se confirmó que los diaptomidos más comunes en la Península de Yucatán fueron: Arctodiaptomus dorsalis y Mastigodiaptomus nesus. El primero se registró también en el lago de Amatitlán. Mastigodiaptomus nesus está ampliamente distribuido al igual que $A$. dorsalis, pero se encuentra ausente en el área del Lago Petén en Guatemala. Mastigodiaptomus reidae fue localizado en dos hábitats poco profundos, éstos especímenes difieren de los tipos de la localidad, por tener un grupo de espinas de gran tamaño en la última parte de la caja toráxica y los segmentos del urosoma de las hembras. Leptodiaptomus siciloides se encontró sólo en el Lago Ayarza, el cual contiene alta salinidad. Prionodiaptomus colombiensis se localizó en las tierras altas de Guatemala en el Lago de Güija y en la zona del Petén en Laguna Sacpuy. Se contribuye con registros de presencia de especies para un mejor conocimiento de la distribución geográfica de algunos copépodos calanoides. De la misma forma, los hallazgos morfológicos en algunas especies son de gran valor taxonómico para la diferenciación de especies.

Palabras clave: América Central, zooplancton, copépodos calanoides, Pseudodiaptomidae, Diaptomidae, distribución geográfica.

\section{REFERENCES}

Bowman, T.E. 1986. Freshwater calanoid copepods of the West Indies. Syllogeus 58: 237-246.

Brandorff, G.O., V. Pinto-Silva \& A.A.E.T. Morini. 2011. Zooplankton: species diversity, abundance and community development, p. 353-389. In W.J. Junk, C.J. da Silva, C.N. da Cunha \& K.M. Wantzen (eds.). The Pantanal: Ecology, biodiversity and sustainable management of a large Neotropical seasonal wetland. Pensoft, Sofia, Bulgaria.

Brinson, M.M. \& G.G. Nordlie. 1975. Lake Izabal, Guatemala. Verh. Internat. Verein. Limnol. 19: 1468-1479.

Cervantes-Martínez, A., M. Elías-Gutiérrez, M.A. Gutiérrez-Aguirre \& A.A. Kotov. 2005. Ecological remarks on Mastigodiaptomus nesus Bowman. 1986 (Copepoda: Calanoida) in a Mexican karstic sinkhole. Hydrobiologia 542: 95-102.

Cicchino, G., E.N. Santos Silva \& B. Robertson. 2001. A new species of Notodiaptomus Kiefer, 1936 (Copepoda, Diaptomidae) from the Amazon and Orinoco river basins. Hydrobiologia 453/454: 539-548.

Cicchino G., E.N. Santos Silva \& E. Zoppi de Roa. 2004. A new species of Prionodiaptomus (Copepoda: Diaptomidae) from the Manu River, Peru. Zool. Stud. 43: 425-434.

Cowardin, L.M., V. Carter, F.C. Golet \& E.T. LaRoe. 1979. Classification of wetlands and deepwater habitats 
of the United States. U.S. Department of the Interior, Fish and Wildlife Service, Washington, D.C. Jamestown, ND: Northern Prairie Wildlife Research Center. (Downloaded: July 8, 2008, www.npwrc. usgs.gov/resource/wetlands/classwet/index.htm (Version 04DEC1998)

Deevey, E.S., G.B. Deevey \& M. Brenner. 1980. Structure of zooplankton communities in the Peten Lake District, Guatemala, p. 669-678. In W.C. Kerfoot (ed.). Evolution and Ecology of Zooplankton Communities. The University of New England, Hanover, New Hampshire, USA.

Dodds, G.S. 1926. Entomostraca from the Panama Canal Zone with description of one new species. Occas. Paper. Mus. Zool. Univ. Mich. 174: 1-27.

Dodson, S.I. \& M. Silva-Briano. 1996. Crustacean zooplankton species richness and associations in reservoirs and ponds of Aguascalientes State, Mexico. Hydrobiologia 325: 163-172.

Dussart, B.H. 1984. Some Crustacea Copepoda from Venezuela. Hydrobiologia 113: 25-67.

Dussart, B.H. \& D. Defaye. 2001. Introduction to the Copepoda. Leiden, Backhuys, Netherlands.

Dussart, B.H., C.H. Fernando, T. Matsumura-Tundisi \& R.J. Shiel. 1984. A review of systematics, distribution and ecology of tropical freshwater zooplankton. Hydrobiologia 113: 77-91.

Elías-Gutiérrez, M., F. Martínez Jerónimo, N.V. Ivanova, M. Valdez-Moreno \& P.D.N. Hebert. 2008a. DNA barcodes for Cladocera and Copepoda from Mexico and Guatemala, highlights and new discoveries. Zootaxa 1839: 1-42.

Elías-Gutiérrez, M., E. Suárez Morales, M.A. Gutiérrez Aguirre, M. Silva Briano, J.G. Granados Ramírez \& T. Garfias Espejo. 2008b. Cladocera y Copepoda de las aguas continentales de México. Guía ilustrada. UNAM, ECOSUR, México.

Flores-Nava, A. 1994. Algunos datos limnológicos de cinco cuerpos acuáticos de Yucatán como base para el desarollo de la acuacultura. An. Inst. Cienc. Mar Limnol. 21: 87-98.

Fosshagen, A. \& T.M. Iliffe. 2003. Three new genera of the Ridgewayiidae (Copepoda, Calanoida) from anchialine caves in the Bahamas. Sarsia 88: 16-35.

Fosshagen, A. \& T.M. Iliffe. 2004. New epacteriscids (Copepoda, Calanoida) from anchialine caves in the Bahamas. Sarsia 89: 117-136.

Gaviria, S. 1989. The calanoid fauna (Crustacea, Copepoda) of the Cordillera Oriental of the Colombian Andes. Hydrobiologia 178: 113-134.
Gaviria, S. 1994. Los copepodos (Arthropoda, Crustacea) de vida libre de las aguas continentales de Colombia. Rev. Acad. Colomb. Cienc. Exact. Fis. Nat. 19: 361-385.

Gophen, M. \& P.D. Walline. 2005. The limnology of Lake Ilopango, El Salvador. Verh. Internat. Verein. Limnol. 29: 799-801.

Gutiérrez-Aguirre, M.A. \& E. Suárez-Morales. 2000. New extension range of the diaptomid copepod Prionodiaptomus colombiensis Thiebaud, 1912 (Copepoda, Calanoida) with complementary description of this species. Zoosystema 22: 507-516.

Gutiérrez-Aguirre, M.A. \& E. Suárez-Morales. 2001. Diversity and distribution of freshwater copepods (Crustacea) in southeastern Mexico. Biodiv. Conserv. 10: 659-672.

Hartmann, G. 1959. Beitrag zur Kenntnis des NicaraguaSees unter besonderer Berücksichtigung seiner Ostracoden (mit Beschreibung von 5 neuen Arten). Zool. Anz. 162: 269-294.

Herbst, H.V. 1960. Copepoden (Crustacea, Entomostraca) aus Nicaragua und Südperu. Gewäss. Abwäss Heft 27: $27-54$.

Juday, C. 1914. A new species of Diaptomus. Trans. Wis. Acad. Sci. Arts Lett. 17: 803-805.

Juday, C. 1915. Limnological studies on some lakes in Central America. Trans. Wis. Acad. Sci. Arts Lett. 18: $214-250$

Kiefer, F. 1956. Freilebende Ruderfußkrebse (Crustacea Copepoda). I. Calanoida und Cyclopoida. Ergebnisse der Deutschen Limnologischen Venezuela-Expedition 1952, p. 233-268. In F. Gessner \& V. Vareschi (eds.). VEB, Berlin, Germany.

Light, S.F. 1939. New American subgenera of Diaptomus Westwood (Copepoda, Calanoida). Trans. Am. Microsc. Soc. 58: 473-484.

Marsh, C.D. 1913. Report on fresh-water Copepoda from Panama, with descriptions of new species. Smithson. Misc. Collect. 61: 1-31.

Marsh, C.D. 1919. Report on a collection of Copepoda made in Honduras by F. J. Dyer. Proc. U. S. National Mus. 55: 545-548.

Marsh, C.D. 1931. On a collection of Copepoda made in El Salvador by Samuel F. Hildebrand and Fred J. Foster of the U. S. Bureau of Fisheries. J. Wash. Acad. Sci. 21: 207-209.

Medeiros, G.F., L.S. Medeiros, D.M.F. Henriques, M.T. Lima e Carlos, G.V.B.S. Faustino \& R.M. Lopes. 2006. Current distribution of the exotic copepod 
Pseudodiaptomus trihamatus Wright, 1937 along the northeastern coast of Brazil. Braz. J. Oceanogr. 54: $241-245$.

Montiel, E. \& E. Zoppi de Roa. 1979. Notas sobre la disposición horizontal de Copépodos en un cuerpo de agua temporal en el Alto Apure, Venezuela. Acta Biol. Venez. 10: 109-128.

Pearse, A.S. 1915. An account of the Crustacea collected by the Walker Expedition to Santa Marta, Colombia. Proc. U. S. National Mus. 49: 531-556.

Pérez, L., R. Bugja, J. Lorenschat, M. Brenner, J. Curtis, P. Hoelzmann, G. Islebe, B. Scharf \& A. Schwalb. 2010. Aquatic ecosystems of the Yucatán Peninsula (Mexico), Belize, and Guatemala. Hydrobiologia 661: 407-433.

Pereira, J.B. \& L. Loureira Fernandes. 2000. Variação temporal do zooplâncton da Lagoa da UFES, Vitória, Espirito Santo. Acta Limnol. Brasil. 11: 79-88.

Reid, J.W. 1997. Argyrodiaptomus nhumirim, a new species, and Austrinodiaptomus kleerekoperi, a new genus and species, with description of Argyrodiaptomus macrochaetus Brehm, new rank, from Brazil (Crustacea: Copepoda: Diaptomidae). Proc. Biol Soc. Wash. 110: 581-600.

Reid, J.W. 2007. Arctodiaptomus dorsalis (Marsh): A case history of copepod dispersal. Banisteria 30: 3-18.

Reid, J.W., I.A.E. Bayly, G.L. Pesce, N.A. Rayner, Y.R. Reddy, C.E.F. Rocha, E. Suárez-Morales \& H. Ueda. 2002. Conservation of continental copepod crustaceans, p. 253-262. In E. Escobar-Briones \& F. Alvarez (eds.). Modern Approaches to the Study of Crustacea. Kluwer Academic/Plenum, New York, USA.

Reid, J.W. \& L.J. Hribar. 2006. Records of some Copepoda (Crustacea) from the Florida Keys. Proc. Acad. Nat. Sci. Philadelphia 155: 1-7.

Santos Silva, E.N. 2008. Calanoid of the families Diaptomidae, Pseudodiaptomidae, and Centropagidae from Brasil. Biol. Geral Exper. 8: 3-67.

Schmitter-Soto, J.J., F.A. Comin, E. Escobar-Briones, J. Herrera-Silveira, J. Alcocer, E. Suárez-Morales, M. Elías-Gutiérrez, V. Diaz-Arce, L.E. Marin \& B Steinich. 2002. Hydrogeochemical and biological characteristics of cenotes in the Yucatan Peninsula (SE Mexico). Hydrobiologia 467: 215-228.

Serruya, C. \& U. Pollingher. 1983. Lakes of the Warm Belt. Cambridge University, Cambridge, USA.

Sárez-Morales, E. 2003. Historical biogeography and distribution of the freshwater calanoid copepods
(Crustacea: Copepoda) of the Yucatan Peninsula, Mexico. J. Biogeogr. 30: 1851-1859.

Suárez-Morales, E. \& M. Elías-Gutiérrez. 2000. Two new Mastigodiaptomus (Copepoda, Diaptomidae) from southeastern Mexico, with a key for the identification of the known species of the genus. J. Nat. Hist. 34: 693-708.

Suárez-Morales, E. \& M. Elías-Gutiérrez. 2001. On the taxonomical status of Arctodiaptomus dampfi Brehm (Crustacea: Copepoda: Diaptomidae) with comments on A. dorsalis (Marsh). J. Limnol. 60: 11-18.

Suárez-Morales, E. \& J.W. Reid. 2003. An updated checklist of the continental copepod fauna of the Yucatan Peninsula, Mexico, with notes on its regional associations. Crustaceana 76: 977-991.

Suárez-Morales, E., J.W. Reid \& M. Elías-Gutiérrez. 2005. Diversity and distributional patterns of Neotropical freshwater copepods (Calanoida: Diaptomidae). Int. Rev. ges. Hydrobiologia 90: 71-83.

Thiebaud, M. 1912. Copépodes de Colombie et des Cordillères de Mendoza. Mem. Soc. Neuchat. Sci. Nat. 5: 160-175.

Torke, B. 2001. The distribution of calanoid copepods in the plankton of Wisconsin lakes. Hydrobiologia 453/454: 351-365.

Torres, R. \& E. Zoppi de Roa. 2010. Latencia en cladóceros y copépodos (Crustacea) de un humedal de la península de Paria, Venezuela. Métod. Ecol. Sist. 5: 23-35.

Walter, T.C. 1989. Review of the new world species of Pseudodiaptomus (Copepoda: Calanoida), with a key to the species. Bull. Mar. Sci. 43: 590-628.

Williamson, C.E. \& J.W. Reid. 2001. Copepoda, p. $915-$ 954. In J.H. Thorp \& A.P. Covich (eds.). Ecology and Classification of North American Freshwater Invertebrates. Academic, San Diego, USA.

Wilson, M.S. 1941. New species and distribution records of diaptomid copepods from the Marsh collection in the United States National Museum. J. Wash. Acad. Sci. 31: 509-515.

Wright, S. 1927. A revision of the South American species of Diaptomus. Trans. Am. Microsc. Soc. 46: 73-121.

Wright, S. 1936. A revision of the South American species of Pseudodiaptomus. An. Acad. Bras. Cienc. 8: 1-24.

Zaret, T.M. \& J.S. Suffern. 1976. Vertical migration in zooplankton as a predator avoidance mechanism. Limnol. Oceanogr. 26: 804-813. 